УДК 811.51

\title{
Phonosemantics in the Language for Special Purposes
}

\author{
Olga A. Bartashova* \\ St. Petersburg State University of Economics \\ 30/32 Nab. kanala Griboedova, St. Petersburg, 191023, Russia
}

Received 13.02.2016, received in revised form 27.02.2016, accepted 01.03.2016

\begin{abstract}
The article is dedicated to the problem of phonosemantic elements in the lexis functioning in languages for special purposes. The concern about inoccurence of phonosemantic words suggests the idea of their limited use and, in particular, their limited performance only in expressive layers of the language. The heuristic potential of phonosemantics gives the ground for hypothesizing the existence of this phenomenon in subsystems standing far from the expressiveness - in terminology which constitutes the core of the language for special purposes, and in the sphere of professional jargons.
\end{abstract}

Keywords: phonosemantics, sound-imitative lexis, sound-symbolic lexis, sound metaphor, terminology, professional jargon, professional sublanguage, onomasiologo-semasiological interpretation of term neutrality.

DOI: 10.17516/1997-1370-2016-9-3-588-594.

Research area: philology.

\section{Introduction}

The language for special (professional) purposes is defined as "a formalized and codified variety of language, used for special purposes with the function of communicating information of a specialist nature of any level in the most economic, precise and unambiguous terms possible" (Pitch, Drascau, 1985). The language for special purposes is commonly associated with the research on the means of special concepts (notion) language representation. The professional sublanguage has been analyzed as a complex of terminological means used in texts of the certain professional field (Leichik, 2009).
Any professional sublanguage can be described as a field-structure. As a rule, it has a core which consists of different terms, denoting special concepts. Apart from a set of terms, professional sublanguage also includes professional jargon which can be referred to the periphery. In other terms, the professional sublanguage presents a two-level system, the sub-level of which includes codified elements, actualized by terms, and the super-level is constituted by non-codified lexis, represented by professional jargon.

There is a widely held belief, that the presence of phonosemantic phenomenon in such a "strict" lexical layer as terminology is impossible. A "glass ceiling" between

\footnotetext{
(C) Siberian Federal University. All rights reserved

* Corresponding author E-mail address: bartashova_o@mail.ru
} 
this phenomenon and terminology is built, on the one hand, by quasi-incompatibility of the expressive and figured character of phonosemantically charged lexis (soundimitative and sound-symbolic words), and, on the other - by a neutral stability of the term. Nevertheless, phonosemantics by itself is an "interdisciplinary science", and since so, the implementation of its ideas in solving crossdisciplinary problems appears to be quite effective (Voronin, 2006). That is the reason why the problem of identification of imitative features in terminology naturally complements the list of phonosemantic researches and can prove the basic idea of this linguistic branch about quite a notable existence of imitative words in the language system.

\section{Theoretical framework}

I.N. Gorelov, by investigating the chain of Russian words капать - капля - каплевидный (kapat' - kaplya - kaplevidnii) in fact, pioneered the idea declaring that "phonosemantics penetrates with the terminology" (Gorelov, 1974).

To perceive this fact and analyse the whole process, we should consider the nature of term. The evolution of terminological studies has resulted in the idea that the term does not present a specific word surrounded by "specific" and sometimes "over-strict" requirements. The current linguistic explanation for the term declares it to be not a special word, but a word, operating in a specific function. The terminology does not perform as an absolutely closed system: it actively interacts with the common-literal lexis and is based on its substrate. One of the results of this process may well be explained by the semantic way of term derivation from a common-literal word.

At the stage of term-formation (literally, at the moment of a special object nomination) its form, as a rule, is motivated. The features of the special object under nomination can serve as motives for nomination. But the scholars of terminology assert that though at the moment of nomination the form of term is motivated, this motivation (inner form) disappears as soon as the nomen defines a special concept and starts functioning as a term (Leichik, 2009).

\section{Point of view}

To answer the question how imitative elements get into a "neutral" terminology, it is necessary both to take into consideration and distinguish two scientific visions on terminology: onomasiological and semasiological. According to these two approaches the interpretation of the "neutrality" of the term might be defined in the following way: semasiologically the term itself is neutral, since the tight connection of the term with its notion, which is free from any emotional or volitional connotations, differentiates it from other commonly used words. The term is neutral semasiologically, but it can not necessarily be neutral by its inner form, i.e. within the context of motivational or onomasiological aspects. If we consider any term from the onomasiological and motivational viewpoint, the entering mechanism of the imitative complex into the terminology is the following: a generic word, the nomination of which is based on a sound (as in the case of a sound imitative word) or on a feature presenting any other sensorial perception of a person (as in the case of sound symbolic lexis) by undergoing the process of semantic evolution develops its terminological meaning (Bartashova, 1987). For example, zipper (meaning "unknitting seam at a different depth trawl's bottom") as a nautical term has appeared as the result of semantic shift from zipper (a device that is made of two rows of metal or plastic teeth and another piece that slides over the teeth to make them fit together or apart and that is used to fasten clothing), which, in its turn, has derived from a zip (a sudden sharp hissing or sibilant sound). 
The mechanism of term creation by means of concept transfers involves redistribution of semes of the initial and new terminalogical meanings, and as a result of this both - source and target meanings - turn to be connected by mutual semes. The process of imitative term-formation is described by metaphorical and metonymical shifts as well as by the meaning narrowing (specialization). The specific character of metaphorical shifts is a symmetrical relations between two notions (or, speaking in the terms of cognitive approach, concepts) with the change of archiseme and redistribution of differential and potential semes (Bartashova, 2015).

Under this process, there are cases of a sound metaphor corresponding as a transfer of one name of the sound, which possesses certain psychoacoustic characteristics, onto the other one, possessing similar psychoacoustic characteristics (Afanasiev, 1984). Within the term-formation through the sound metaphor, we can observe preservation of the archiseme "sound" that allows the term to stay within its natural phonosemantic environment. Alongside with this transfer, a change of relative (additional) semes marking the source of the sound takes place. Due to this change, the introduction of the imitative word into the terminology occurs: ping (1. a sharp sound like that of a striking bullet; 2. a sharp, high-pitched, metallic sound in the engine).

Such primary shifts (i.e. shifts that reflect a direct correlation between the basic sound meaning and meaning of the first level of diachronic derivation) appear within the terminological meaning formation, though these cases of sound metaphor are not so frequent.

\section{Primary and secondary motivated terms of phonosemantic origin}

The professional sphere to be analysed in this article is English nautical terminology. It is not a strictly closed terminological system: its openness comes from the fact that the history of its formation is closely connected with the history of the evolution of the English language. The nautical terminology is one of the oldest and well-developed layers of the national English language, as for the British Isles all types of activities connected with the sea have traditionally been of the vital importance. Historically, nautical professions have always been very popular in England and, consequently, nautical terminology is closely interconnected with the lexis of common use.

The English nautical terminological system contains the terms initially suggesting a direct primary phonetic motivation. Thus, for example, bunt (meaning "the middle part of a sail") originated as a nautical term. Primary motivation can be exemplified by the following nautical terms: clamp, jib, buoy, poop, chung. Nevertheless, primarily motivated terms are not so numerous.

As a rule, phonosemantically marked nautical terms are the result of semantic shifts (metaphorical, metonymical), reflecting the correlation of meanings which belong to the second and following levels of the semantic derivation. There are rare cases of sound metaphor (i.e. transfer of one name of the sound, which possesses certain psychoacoustic characteristics, onto the other one, possessing similar psychoacoustic characteristics of the special (technical) object, producing this sound): clank - if a heavy metal object clanks or if you clank it, it makes a short loud sound / the sound of a machine.

Metaphorical transfers of the second and other levels of semantic derivation are performed according to different models:

- a slush: partly melted snow / any watery muddy substance; 
- to wobble: to move with an unsteady side-to-side motion / to hesitate or lose confidence about doing something;

- a whiff: a quick puff or slight gust especially of air/clipper;

- to choke: to interfere with the respiration of by compression or obstruction of the larynx or trachea/ to decelerate;

Primary metonymical transfers reflect the correlation of sound meanings and the source feature. As a rule, they are causal transfers such as "sound" - "technical object" (phenomenon), the performance of which is accompanied by this sound":

- a clack: a short sharp sound/ a flapper

- a pip: a short high-pitched tonel an impulse on the echo sounding machine screen

Secondary metonymic transfers are characterized by a wide range of patterns:

1. Causal:

- a bump: an act of something hitting against something else /speed-up of the stern or bow due to the waving;

- to slip: to move with a smooth sliding motion/shipbuilding ways;

2. Locative:

- a swash: a splashing sound/ a narrow fairway between two shelves;

- to drip: to fall in drops / collecting pan;

3. Attributive:

- a burr: wind/ capacity of the wind

- a grit: very small pieces of sand or stone /grain.

Most of the phonosemantically marked terms are formed by narrowing of the meaning - the mechanism which reflects the change of a word from the sphere of common use to a specific professional one, together with narrowing of the notion, but expanding of its content:
- to jump: an act of jumping/ temperature jump; rise of pressure;

- to hover: to remain floating, suspended, or fluttering in the air/ a "submarine" conditions.

There are also cases of sound specialization, i.e. a shift that together with additional differential semes contains the archiseme "sound", which allows the term to stay in its original phonosemantic sphere.

There is a particular correlation between the density of imitative terminological lexis and the character of the terminological system:

1) the more open the system is (i.e. if there is close connection between the terminological system and commonly used words), the more phonosemantic elements it contains;

2) the more concrete the term system is, the more phonosemantic components it contains; the more abstractive it is, the less phonosemantic components it contains.

Thus, for example, the English professional sublanguage of dance is another type of an open terminological system. Here we can discover a lot of terms of phonosemantic origin which nominate types of dances and movements: click heels, jig step, swirl, dab, scoot, scuff, hip-hop, break, clip etc.

The English military term system is also not a closed one: it interacts with the language of common use quite intensively. Thus, it has a lot of phonosemantically marked terms, which originated from phonosemantic stems:

- a bullet : a small piece of metal or another material that is shot out of a gun;

- blocking and chocking : the use of wedges or chocks to prevent the inadvertent shifting of cargo in transit;

- to seize: to employ combat forces to occupy physically and to control a designated area; 
- a strike: an attack to damage or destroy an objective or a capability;

- a lightening: the operation (normally carried out at anchor) of transferring crude oil cargo from a large tanker to a smaller tanker;

- a blast: rocket firing/missile launch.

Terms of technical terminological system, based on common language substrate, get phonosemantic status when they are semantically developed from commonly used words of soundimitative or sound-symbolic origin:

- a blurred image: out-of-focus imagel unsharp image;

- a buzzer: beep tonel hummer (an instrument);

- to chatter: to cracklel to make an additional noise;

- a clincher: an instrument used to fasten papers.

On the other hand, in the professional jargon, that is also a type of the language used by a particular professional group or occupation, one can regularly observe a non-arbitrary interrelationship between the sound-form of a word and the emotional coloring of its meaning. Phonosemantically marked words can appear in professional jargon as new onomatopoetic stems (primary motivation):

- a dud (military jargon): explosive that fails to fire or detonate, respectively, on time or on command;

- a hock (Am.slang): a prison;

- a boffin: meaning a scientist who deals with radars;

- a fink: an employee who refuses giving up work during the strike.

Otherwise onomatopoetic stems can penetrate into professional jargon as the result of semantic derivations (secondary motivation):

- a crook: a hook/ a deceiver, criminal;
- a hiccup: a short repeated sound that you make in your throat without intending to / short-term softening of the market;

- a drummer: a person who plays drums / ability to attract attention/ sales representative;

- to gobble up: to eat quickly / to make a maximum use of funds;

E.S. Tatarinova in her research on phonosemantics in the professional economic jargon has marked such a feature of the phonosemantic jargon as its "hyperexpressiveness", which can be explained by the fact that professional words, which are derived from onomatopoetic stems, being expressive by definition, double their expressiveness through the expressive means of the word-formation (Tatarinova, 2006). Sound symbolism and sound imitation are the main phonetical means, which add the expressivity to any word and, in this very way, the expressive intensification, or hyperexpressivity is regularly actualized in professional jargons: this phenomenon is peculiar to pure reduplications, rhymed and ablautized constructions. To support the idea of hyperexpressivity, there are the following examples of jargons taken from the sphere of economics:

- razzle-dazzle: (the sound symbolic stem means can be considered as pejorative)wasteful advertising,

- flip-flop arbitration (the sound imitation feature of reduplication nominating "clap" or "twisting in the air", "wave-like moving"): similar to the phonosemantic reduplication flip-flap: a type of interest arbitration in which the arbitrator chooses one of the parties' proposals on each disputed issues; used to avoid strikes;

- to squeeze: (the sound symbolic stem means "constricting") in squeeze and 
freeze - governmental measures on control over wages and keeping prices down;

- yo-yo: (a reduplicative construction with the sound symbolic stem meaning “waving” or "vary") price fluctuations (Tatarinova, 2006).

Participating in complex semantic changes, primary motivated onomatopoetic stems, as a rule, lose the connection between their phonetic forms and meanings, i.e. they denaturalize (Voronin 2006). Otherwise, phonosemantic words, which have once been phonetically motivated, by going through a number of semantic transformations and staying at a certain level of denaturalization, in professional jargons can still be recognized as phonosemantic due to "renaturalized" meanings rebuilding that primary motivation.

\section{Conclusion}

The main content of the work is connected with the study of phonosemantic elements in the lexis functioning in languages for special purposes. In the thesis study it has been shown that a heuristic potential of phonosemantics gives the ground for hypothesizing the existence of this phenomenon in different subsystems of professional languages, so widely spaced from the expressiveness, i.e. in terminology which is considered to be a central part (or, in fact, a core) of the language for special purposes and of the professional jargon. The choice of onomasiologico - semasiological approach to the interpretation of the neutrality of the term provides an opportunity to describe the mechanism of penetrating phonosemantic phenomenon into lexis, circulating within the languages for special purposes, i.e. terms and professional jargonisms. This work brings the light on the fact, that phonosemantically charged words are not so limited in their number and function even in so "strictly described" terminological systems, since terms may well concede both primary and secondary motivation. Generally, the density of phonosemantic elements in terminological systems depends on the degree of its openness: terms of phonosemantic origin are more likely to be identified in non-strictly isolated terminological systems.

In professional jargons one can regularly observe a non-arbitrary interrelationship between the sound-form of a word and the emotional coloring of its meaning. That brings us to say, that phonosemantically marked words can appear in professional jargon as new onomatopoetic stems or as a result of semantic derivations of the words with phonosemantic origin. Being used in professional jargons, they are often perceived as onomatopoetic ones, due to the phenomenon of renaturalization.

\section{References}

Afanasiev, A. Iu. (1984). Voprosy semanticheskoi evoliutsii leksiki (na materiale angliiskih zvukopodrazhatelnih sushchestvitelnih): dis. ... kand. filol. nauk [Problems of the semantic evolution of lexis (a case study of English sound imitative nouns): Doctoral Thesis (Philology)]. Leningrad, $211 \mathrm{p}$.

Bartashova, O.A. (1987). Revisiting the "term neutrality" (through the example of terms in the English language) [K voprosu o «neitralnosti termina» (na materiale angliiskih terminov so zvukoizobrazitelnoi osnovoi)]. Nauchno-texniheskaia terminologiia i perevod: Materialy zonalnoi nauchno-prakticheskoi konferentsii [Scientific and technical terminology and translation: Proc. Regional Research and Practice Conference]. Chelyabinsk, 78-92.

$$
-593-
$$


Bartashova, O.A. (2015). Metaphoric power of phonosemantically charged lexis, In Journal of Siberian Federal University, 12 (8), available at: http://elib.sfu kras.ru/bitstream/2311/19968/1/02 Bartashova.pdf

Gorelov, I.N. (1974). Problema funktsionalnogo bazisa rechi v ontogeneze [Problem of the speech's functional basis in the ontogeny]. Cheliabinsk, Chel. Gos. Pedagogicheskii Universitet, $116 \mathrm{p}$.

Leichik, V.M. (2009). Terminovedenie: Predmet, metody, struktura. Izd. 4 [Terminology studies: subject, methods and structure. $4^{\text {th }}$ Ed.]. Moscow, Knizhnii dom LIBROKOM, $256 \mathrm{p}$.

Picht, H., Draskau, J. (1985). Terminology: an introduction. Guilford, University of Surrey.

Tatarinova, E.S. (2006). Zvukoizobrazitelnost $v$ angliiskom professionalnom zhargone (na materiale ekonomicheskogo zhargona): dis...kand. filol. nauk [Phonosemantics in the English professional jargon (a case study of economical jargons): extended abstract of Cand. Sci. (Philology) thesis]. Saint-Petersburg, $23 \mathrm{p}$.

Voronin, S.V. (2006). Osnovy fonosemantiki. Izd. 2 [Foundations of phonosemantics. $2^{\text {nd }}$ Ed.]. Moscow, LENAND, $248 \mathrm{p}$.

\title{
Фоносемантика в языке \\ для специальных целей
}

\author{
О.А. Барташова \\ Санкт-Петербургский государственный \\ экономический университет \\ Россия, 191023, Санкт-Петербург, наб. Канала Грибоедова, 30/32
}

\begin{abstract}
В статье рассматривается вопрос о фоносемантических компонентах в лексике языка для специальных иелей. Мнение о нераспространенности фоносемантической лексики наводит на мысль об ее ограниченном использовании, ее преимущественном функиионировании в экспрессивных слоях языка. Эвристический потенциал фоносемантики дает основание исследовать это явление в далекой от экспрессивности подсистеме - терминологии, являюшейся ядром языка для спеииальных иелей, и сферы профессионального жаргона.
\end{abstract}

Ключевые слова: фоносемантика, звукоподражательная лексика, звукосимволическая лексика, звуковая метафора, терминология, профессиональный жаргон, ономасиологосемасиологическое понимание нейтральности термина.

Научная специальность: 10.00.00 - филологические науки. 